\title{
Reduction of Aeromonas hidrophyla biofilm on stainless stell surface by essential oils
}

\author{
Alessandra Farias Millezi ${ }^{1}$, Maria das Graças Cardoso ${ }^{2}$, \\ Eduardo Alves ${ }^{3}$, Roberta Hilsdorf Piccoli ${ }^{4}$ \\ ${ }^{1}$ Instituto Federal Catarinense, Campus Concórdia, Concórdia, SC, Brazil. \\ ${ }^{2}$ Departamento de Química, Universidade Federal de Lavras, Lavras, MG, Brazil. \\ ${ }^{3}$ Departamento de Fitopatologia, Universidade Federal de Lavras, Lavras, MG, Brazil. \\ ${ }^{4}$ Departamento de Ciência dos Alimentos, Universidade Federal de Lavras, Lavras, MG, Brazil.
}

Submitted: April 16, 2011; Approved: July 2, 2012.

\begin{abstract}
This study demonstrates the possibility of using sanitizing detergents based on natural products for the elimination and/or reduction of Aeromonas hydrophila biofilm formed on stainless steel surfaces. The goal of this work was to determine the reduction effect of sanitizing detergents containing essential oils of Thymus vulgaris (thyme) and Cymbopogon citratus (lemongrass) on biofilm formed by $A$. hydrophila on AISI 304 stainless steel coupons, using UHT skimmed milk as substratum. There was adhesion and biofilm formation by $A$. hydrophila at $28^{\circ} \mathrm{C}$, presenting $7.60 \log \mathrm{cfu} . \mathrm{cm}^{-2}$ after the fourth day of cultivation. There was no significant difference between the lemongrass treatment and that of the thyme oil $(\mathrm{p}<0.05)$. However, both treatments significantly reduced the biofilm, differing significantly from the $\mathrm{NaOH}$ control $(\mathrm{p}>0.05)$. The treatment with lemongrass solution reduced the biofilm by $4.51 \log \mathrm{cfu} \mathrm{cm} \mathrm{cm}^{-2}$ at $25^{\circ} \mathrm{C}$. The thyme detergent also reduced the number of $\mathrm{cfu} \mathrm{cm}^{-2}$ by $3.84 \log$ cycles at $25^{\circ} \mathrm{C}$. The use of the lemongrass and thyme solutions efficiently reduced the $A$. hydrophila biofilm.
\end{abstract}

Key words: Thymus vulgaris, Cymbopogon citratus, natural disinfectants, sanitation.

\section{Introduction}

Aeromonas hydrophila is recognized for its capacity to produce several virulence factors such as cytotoxins and enterotoxins and adhesion capacity. These factors can cause hemolysis and allow the invasion of epithelial cells (Prigent-Combaret and Lejeune, 1999) causing gastroenteritis in humans. Due to its aquatic origin, it presents a ubiquitous distribution in the environment, being able to present itself in the most varied types of animal products and vegetables, such as fish and meat and its derivatives or any food that comes in contact with water (Trombetta et al., 2005). A. hydrophila is a gram-negative, facultative aerobic, not spore former, catalase-positive, oxidase-positive and has an optimum development temperature of $28{ }^{\circ} \mathrm{C}$ (Joseph and Carnahan, 2003; Lafarge et al., 2004). Due to presence of polar and lateral flagella, this bacterium presents mobility and adhesion and biofilm formation capacity (Gavín et al., 2002).
Biofilms are complex microbiologic ecosystems embedded in matrixes of organic polymers adhered to a surface. Once established, sessile bacteria express genes in a model that differs greatly from that of planktonic bacteria, leading to phenotypic changes (Prigent-Combaret and Lejeune, 1999). One of those outstanding properties is the increase of sessile cell resistance to host defenses, biocides, antibiotics and various physiochemical agents (Costerton, 2005; Rota et al., 2008). Therefore, biofilm cells can persist and survive even after sanitization processes, representing a possible source of food contamination and subsequent food poisoning in humans and animals (Chavant et al., 2007). A large number of studies aiming to find effective elimination and biofilm control strategies have been published (Gandhi and Chikindas, 2007), demonstrating the necessity of obtaining new products with biocide action, seeking the elimination of microbial biofilms and their effective control in food industries.

Send correspondence to A.F. Millezi. Instituto Federal Catarinense, Campus Concórdia, Concórdia, SC, Brazil. E-mail: alessandra.millezi@ifc-concordia.edu.br. 
The interest in natural antimicrobial compounds has been growing due to the changes of consumer attitude toward the use of synthetic food preservation, detergents and sanitizers which possess negative impacts on the environment (Danielsen et al., 2008; Lebert et al., 2007). Thus, the use of essential oils stands out. The action mechanisms of essential oils are little known. Considering the great number of different groups of chemical compounds present in such oils, it is observed that their antibacterial activity is not attributed to a single specific mechanism, which leads to the conclusion that they target several processes in the microbial cell (Mondello et al., 2003; Ogunwande et al., 2005; Suñen et al., 2003).

The species Cymbopogon citratus (A.D.) Stapf., belonging to the family Poaceae (Gramineae), is popularly known by more than 20 names, among these lemongrass, grass-saint lemon verbena, fragrant grass, cidreira grass, lesser citronella and true cidreira herb (Cardoso et al., 2000). The most expressive economical use of C. citratus is the production of its essential oil, rich in citral and widely used in the food, pharmaceutical and cosmetic industries (Cardoso et al., 2000). Studies suggest that the antibacterial activity of $C$. citratus oil is mainly due to the $\alpha$ and $\beta$-citral components present in it (Oliveira et al., 2010). Besides $C$. citratus, the genus Thymus encompasses numerous species and varieties, which have had their essential oils studied (Martins et al., 2004; Onawunmi et al., 1984; Sotomayor et $a l ., 2008)$. It's essential oil is rich in timol, presenting traces of carvacrol, scientifically recognized potent bactericides and fungicides (Essawi and Srour, 2000). More recent studies prove the antibacterial activity of $T$. vulgaris as being effective against gram-positive and Gram negative bacteria (Barbosa et al., 2009).

Aimed at discovering alternate forms of eliminating biofilms formed by $A$. hydrophila on stainless steel surfaces, this work evaluated the sanitizing capacity of sodium hydroxide solutions enhanced with the essential oils of $C$. citratus and T. vulgaris.

\section{Materials and Methods}

\section{Microorganism used and standardization}

Aeromonas hydrophila ATCC 27853 was employed. The growth curves were prepared for standardization of the colony-forming units count. Aliquot of pure cultures $(10 \mu \mathrm{L})$ were transferred to Erlenmeyer flasks containing $200 \mu \mathrm{L}$ of BHI (Brain Heart Infusion) broth and incubated at $28{ }^{\circ} \mathrm{C}$. Growth was monitored every hour through spectrophotometry $(620 \mathrm{~nm})$. The absorbance readings were taken periodically, until $10^{9} \mathrm{cfu} \mathrm{mL}^{-1}$ were obtained.

\section{Plant material}

Dried leaves of $C$. citratus were used, obtained from the Medicinal Plant Nursery of the Federal University of Lavras, (UFLA). The collection was conducted from 8 to 9 o'clock in the morning, on sunny days, in September of 2009 , under a temperature of approximately $20^{\circ} \mathrm{C}$. The $T$. vulgaris dry leaves were acquired from the local commerce of Lavras, MG, Brazil.

\section{Extraction of essential oils and quantification of main constituents}

The essential oil extraction process was conducted using the hydrodistillation method, in a modified Clevenger-type apparatus, adapted with a 4 liter round bottom balloon flask with a ground-glass mouth (Castro et al., 2006).

\section{Quantitative analysis of the constituents of the essential oils}

A Shimadzu model CG-17A gas chromatograph equipped with a flame ionization detector (FID) and a fused-silica capillary column containing a bound DB5 stationary phase ( $30 \mathrm{~m} \times 0.25 \mathrm{~mm})$ were employed for quantitative analysis. The carrier gas was nitrogen, with a flow rate of $2.2 \mathrm{~mL} \mathrm{~min}^{-1}$; the split ratio was $1: 10$, and the injected volume was $1 \mu \mathrm{L}$. The temperatures of the injector and the detector were 220 and $240{ }^{\circ} \mathrm{C}$, respectively. Three injections were performed for each essential oil tested. The apparent average concentration and standard deviation for each constituent were calculated after area normalization (Adams, 2007).

\section{Determination of Minimum Inhibitory Concentration (MIC) of essential oils}

The antimicrobial activity of the essential oils was tested through the agar plate well diffusion method proposed by Deans and Ritchie (1987) and modified by Pereira et al. (2008). The inoculum was standardized at the final concentration of $10^{8} \mathrm{cfu} \mathrm{mL}^{-1}$. Solutions of C. citratus and T. vulgaris oils were used in absolute ethanol at the concentrations of 0 (control), 4, 8, 16, 31, 62, 125, 250 and $500 \mu \mathrm{L} \mathrm{mL}{ }^{-1}$. The plates containing the inoculum and the different oil concentrations were incubated at $28^{\circ} \mathrm{C}$ for $24 \mathrm{~h}$ (Onawunmi, 1984). The diameters of the inhibition zones were measured in millimeters. Ethanol without addition of essential oil was used as control as used in related studies to antibacterial activity using ethanol as an oils diluent (Chorianopoulos et al., 2008; Oliveira et al., 2010; Rota et al., 2008). All tests were performed in triplicate with three replications.

\section{Sanitization of coupons}

In order to initiate the bacterial cell adhesion stage, the coupons and stainless steel passed for a previous process of hygiene and sterilization. First they were cleaned with acetone $100 \%$, rinsed with sterilized distilled water, dried and cleaned with alcohol $70 \%(\mathrm{v} / \mathrm{v})$. After that, they were washed with sterilized distilled water, dried for $2 \mathrm{~h}$ at $70{ }^{\circ} \mathrm{C}$ and autoclaved at $121^{\circ} \mathrm{C}$ for $15 \mathrm{~min}$. 


\section{Adhesion of bacterial cells on stainless steel surface}

The experimental model of biofilm formation by $A$. hidrofhyla was elaborated based on a system first used by Marques et al. (2007). In the present study, the experimental model consisted of 20 stainless steel coupons AISI 304 $(1 \times 10 \times 20 \mathrm{~mm})$ and in Petri dishes $140 \mathrm{~mm}$ diameter containing approximately $25 \mathrm{~mL}$ of UHT skimmed milk. AISI 304 was chosen because it is one of the most used stainless steel. The plates were incubated at $28^{\circ} \mathrm{C}$ for $48 \mathrm{~h}$ and agitated at $50 \mathrm{rpm}$.

\section{Enumeration of adhered bacterial cells}

Initially, $60 \mathrm{~mL}$ of TSB previously sterilized and aliquot of TSB containing the bacterial culture were added to the Petri dish at a final concentration of approximately $5 \mathrm{Log} \mathrm{cfu} \mathrm{mL}^{-1}$. The system containing the coupons was sealed and incubated at $28{ }^{\circ} \mathrm{C}$ under $50 \mathrm{rpm}$ agitation. Every $48 \mathrm{~h}$, the coupons were removed from the base and immersed three times into a saline solution to remove the planktonic cells, and again placed in a new sterilized Petri dish, which was immersed in $60 \mathrm{~mL}$ of TSB. This procedure was repeated every $48 \mathrm{~h}$, completing $240 \mathrm{~h}$ of incubation, to form a mature biofilm.

Every $48 \mathrm{~h}$ the bacterial cells adhered to the coupons were removed using the smear technique. We used standardized sterile swabs (100 times). The swabs were immersed in tubes containing $10 \mathrm{~mL}$ of peptone water $0.1 \%$ $(\mathrm{w} / \mathrm{v})$ and subjected to intense agitation Votex for $3 \mathrm{~min}$. Serial dilutions in peptone water $0.1 \%(\mathrm{w} / \mathrm{v})$ were made ??from the test tube containing the swab, followed by plating aliquots of $100 \mathrm{~mL}$ on the surface of TSA (Silva et al., 2010). The plates were incubated at $28^{\circ} \mathrm{C}$ for $24 \mathrm{~h}$. Analyses were performed every $48 \mathrm{~h}$. The entire procedure was performed in triplicate with three replicates

\section{Aeromonas hydrophila biofilms treatment with essential oils and alkaline detergent}

After $240 \mathrm{~h}$, was performed the treatment of biofilms with the disinfectant solutions-based essential oils. The coupons were previously immersed three times in the saline solution to remove the planktonic cells. After were immersed in solutions: $\mathrm{NaOH}$ solution $(1 \% \mathrm{w} / \mathrm{v})$ with addition of sterile water in place of essential oil, sterilized distilled water containing $\mathrm{NaOH}$ solution with essential oil of $C$. citratus and $\mathrm{NaOH}$ solution containing essential oil of $T$. vulgaris, both oils diluted in absolute ethanol at MIC concentrations determined before, $31 \mu \mathrm{L} \mathrm{mL}^{-1}$ and $62 \mu \mathrm{L} \mathrm{mL}^{-1}$, respectively. The solutions containing the coupons were kept for 15 min (contact time was chosen considering the usefulness of these solution in the process of hygiene at food industries) temperature $20^{\circ} \mathrm{C}$ (Andrade and Macêdo, 1996). After this period the coupons were removed from the solutions, rinses with salt water 3 times and subjected to smear with the swabs and dilution procedure and plating as already described in previous item.

\section{Scanning Electron Microscopy Analysis (SEM)}

The preparation of the coupons for observation via scanning electron microscopy followed the protocol proposed by Alves (2004). All of the procedures were carried out at the Electronic Microscopy and Ultra structural Analysis Laboratory of the Federal University of Lavras, (UFLA), Lavras, Minas Gerais, Brazil.

\section{Statistical analysis}

For the surviving bacteria, the experiment was conducted according to a completely randomized design, with three repetitions. In the treatments were made up of three types of detergent-sanitizers $(\mathrm{NaOH}$, solution of lemongrass essential oil and $\mathrm{NaOH}$, and thyme essential oil added to $\mathrm{NaOH})$ and one temperature $\left(20^{\circ} \mathrm{C}\right)$. Counting of colony forming units $\mathrm{cfu} \mathrm{cm}^{-2}$ were carried out, before and after coupon immersion in the solutions. The results were expressed in the logarithmic form $\left(\log \mathrm{cfu} \mathrm{cm}^{-2}\right)$, the variable being the measure of the ratio (proportion) between the pre-immersion log $\mathrm{cfu} \mathrm{cm}^{-2}$ and post-immersion log cfu $\mathrm{cm}^{-2}$. The analysis was made using the $\mathrm{R}$ Development Colors Team (2008) statistical package. The factors, when significant, were appraised by the Scott-Knott test.

\section{Results}

\section{Main components of essential oils and Minimum Inhibitory Concentration}

Under the conditions used in this study for extraction of essential oils from lemon grass, the main components of the lemongrass were: neral $(32.73 \%)$, geranial $(46.03 \%)$ and myrcene $(8.88 \%)$ (Table 1$)$. The thyme oil was composed mainly by: 1,8 cineole $(53.46 \%)$ and canfhor (7.15\%) (Table 2).

In this study it was found that antimicrobial activity of the essential oils were drawn on the bacteria, the MIC of essential oil of lemongrass, $31 \mu \mathrm{L} \mathrm{mL}^{-1}$ was lower than that of thyme, $62 \mu \mathrm{L} \mathrm{mL}^{-1}$ (Figure 1).

Table 1 - Chemical composition of essential oils of Cymbopogon citratus.

\begin{tabular}{lcc}
\hline Constituintes & $\operatorname{Tr}^{\mathrm{a}}$ & $\%^{\mathrm{b}}$ \\
\hline Myrcene & 12.474 & 8.88 \\
Linalool & 16.601 & 2.23 \\
Verbenol & 18.998 & 1.62 \\
Neral & 21.909 & 32.73 \\
Nerol & 22.318 & 4.07 \\
Geranial & 22.989 & 46.03 \\
Nonyl methyl ketone & 23.597 & 1.56 \\
Methyl undecyl ketone & 30.133 & 1.16 \\
Other & & 1.72 \\
Total & - & 100.00
\end{tabular}

${ }^{\mathrm{a}}$ Retention time. ${ }^{\mathrm{b}}$ The percentages concern the integration of the areas of the peaks. 


\section{Adhesion of bacterial cells on the stainless steel surface}

Aeromonas hydrophila biofilm was grown for 10 days for the training of the mature biofilm (Boari et al., 2009). Selection of $A$. hydrophila was because today is considered an emerging microorganism in food security and stability. This species are psychotropic microorganisms, or even presenting as a growth optimum temperature somewhere around $28{ }^{\circ} \mathrm{C}$, are able to grow at the temperatures used in food preservation (Boari et al., 2009).

Aeromonas hydrophila adhered to the AISI 304 stainless steel surface using the UHT skimmed milk as substra-

Table 2 - Chemical composition of essential oil of Thymus vulgaris.

\begin{tabular}{lcc}
\hline Constituents & $\operatorname{Tr}^{\mathrm{a}}$ & $\%{ }^{\mathrm{b}}$ \\
\hline$\alpha$-tujona & 10.257 & 0.62 \\
$\alpha$-pineno & 10.795 & 4.17 \\
Camphene & 11.765 & 4.20 \\
Sabinene & 11.856 & 4.36 \\
$\beta$-Pinene & 12.449 & 2.51 \\
Myrcene & 13.711 & 1.56 \\
$\rho$-Cimene & 13.872 & 3.79 \\
Limonene & 14.102 & 3.30 \\
1 8-Cineole & 18.288 & 53.46 \\
Canfhor & 19.064 & 7.15 \\
Isoborneol & 19.519 & 2.30 \\
Terpinen-4-ol & 19.980 & 5.46 \\
$\alpha$-terpineole & 23.349 & 1.72 \\
Bornyl acetate & 26.424 & 2.38 \\
Copaene & 26.424 & 2.38 \\
Other & & 064 \\
Total & - & 100.00 \\
\hline & & \\
\hline
\end{tabular}

${ }^{a}$ Retention time. ${ }^{b}$ The percentages concern the integration of the areas of the peaks.

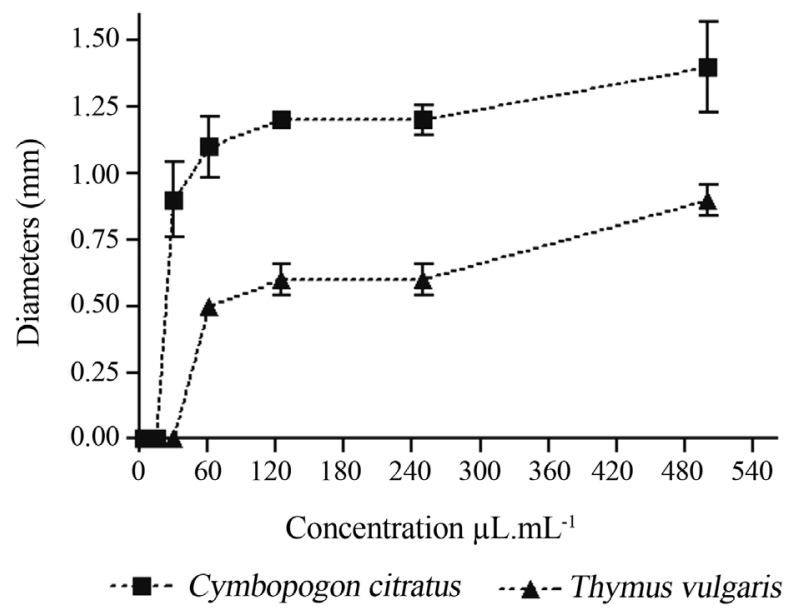

Figure 1 - Inhibition zones by different concentrations of essential oils of Cymbopogon citratus and Thymus vulgaris on Aeromonas hydrophila. tum and formed the biofilm. After two days of cultivation, the bacterium had already formed biofilm on the surface, reaching $6.6 \mathrm{log}$ cycles $\mathrm{cfu} \mathrm{cm}^{-2}$, and after 10 days of cultivation the number of sessile cells increased to $7.8 \mathrm{log} \mathrm{cfu}$ $\mathrm{cm}^{-2}$. Such increase occurred due to the multiplication of the adhered cells, since the milk was replaced every two days with a new sterilized base.

Although the cultivation lasted 10 days, the number of $\mathrm{cfu} \mathrm{cm}^{-2}$ increased slightly more than $1 \log$ cycle, showing that, when cultivated at $28^{\circ} \mathrm{C}$ and in skimmed milk, $A$. hydrophila did not form thick biofilm.

\section{Disinfectant and biocide action against Aeromonas hydrophila biofilm}

For the evaluation of the detergent-sanitizing solutions' efficiency (essential oil and $\mathrm{NaOH} 1 \%$ ), the MIC of the thyme essential oil $\left(62 \mu \mathrm{L} \mathrm{mL}{ }^{-1}\right)$ and the lemongrass oil's $\left(31 \mu \mathrm{L} \mathrm{mL}^{-1}\right)$ were used. The results were expressed by the number of log cycles of $\mathrm{cfu} \mathrm{cm}^{-2}$ of the bacterial population remaining on the coupons after the treatments. The efficiency of the detergent-sanitizing solutions of thyme essential oil, lemongrass essential oil and that of the alkaline detergent solution (control, $\mathrm{NaOH} 1 \%$ ), were compared as to the sessile cells removal capacity of the mature biofilm. The treatments were carried out at temperature $25^{\circ} \mathrm{C}$.

The detergent-sanitizing solutions of thyme essential oil, lemongrass essential oil and the alkaline detergent solution reduced bacterial population, resulting in lower log cfu $\mathrm{cm}^{-2}$ values, in comparison to the mature biofilm without treatment (Figure 2).

There was significant difference between the treatments with alkaline detergent $(56.05 \%)$ and with the sanitizing-detergent $(p<0.05)$. However, the difference between the percentages of $\mathrm{cfu} \mathrm{cm}^{-2}$ obtained through the treatment with thyme's sanitizing-detergent $(42.33 \%)$ and those observed on the lemongrass (34.67\%) was not significant $(p>0.05)$. The microbial population of the biofilm

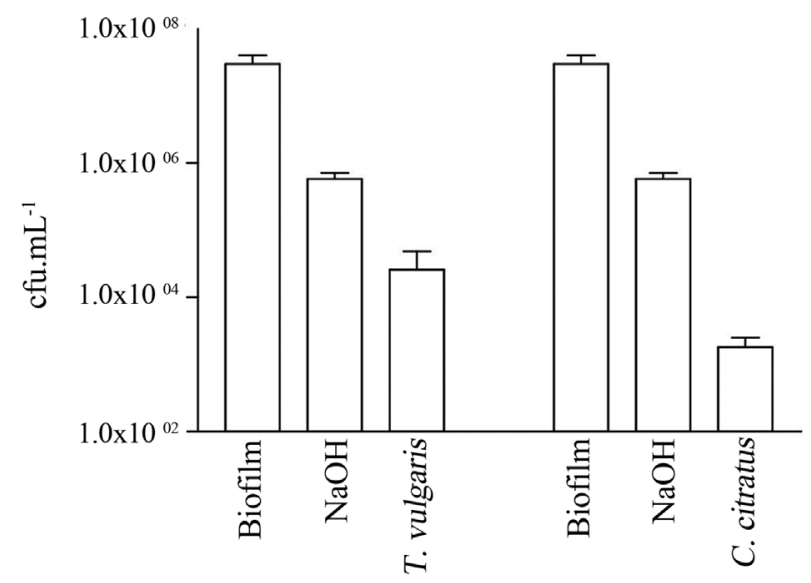

Figure 2 - Concentration of Aeromonas hydrophila $\left(\log \mathrm{CFU} \mathrm{cm} \mathrm{cm}^{-2}\right)$ quantified on steel coupons with and without treatments with essential oils of Cymbopogon citratus and Thymus vulgaris. 
without treatment was $7.63 \log \mathrm{cfu} \mathrm{cm}^{-2}$. Comparing the cfu $\mathrm{cm}^{-2}$ concentrations obtained on the coupons treated with detergent-sanitizer solution plus the lemongrass essential oil at $25{ }^{\circ} \mathrm{C}$ with those on the mature biofilm, it was observed that there were reductions of $4.51 \log \mathrm{cfu} \mathrm{cm}^{-2}$ on the population of A. hydrophila. The thyme essential oil detergent-sanitizer also promoted reductions on population of 3.84 at $25^{\circ} \mathrm{C}$. In biofilms treated only with the solution containing $\mathrm{NaOH}$ was smaller reduction: $2.38 \mathrm{log}$ cycles. In the Figure $3 \mathrm{~A}$ and $3 \mathrm{~B}$ can be observed that the biofilm was cohesive and uniform and there was the production of exopolysaccharides (EPS) and demonstrated the wide grip and different layers. In the micrographs one can observe that after the different treatments, there was breakdown of the EPS and dispersion of cells (Figure 3C and 3D).

No significant interaction between treatments of biofilms between the detergent-sanitizing solution of lemon grass and thyme (Table 3). The concentration $1 \%(\mathrm{p} / \mathrm{v})$ $\mathrm{NaOH}$ alkaline solution reduced the biofilm cell concentration. However, the highest percentage of surviving bacteria $(56.05 \%)$ was obtained. The solutions containing essential oils were more effective in reducing the viable cells in biofilms (Table 3).

\section{Discussion}

Several studies have reported the existence of different chemical characteristics between the essential oils of different species and even between identical species, but grown in different geographical regions of the globe. The main components found in the C. citratus oil, neral and geranial, are monoterpenes, whose antibacterial action is proven (Millezi et al., 2012a; Millezi et al., 2012b; Ogunwande et al., 2005). However, myrcene is an acyclic hydrocarbon, not possessing antibacterial action that polymerizes and resinifies when exposed to light (Onawunmi et al.,
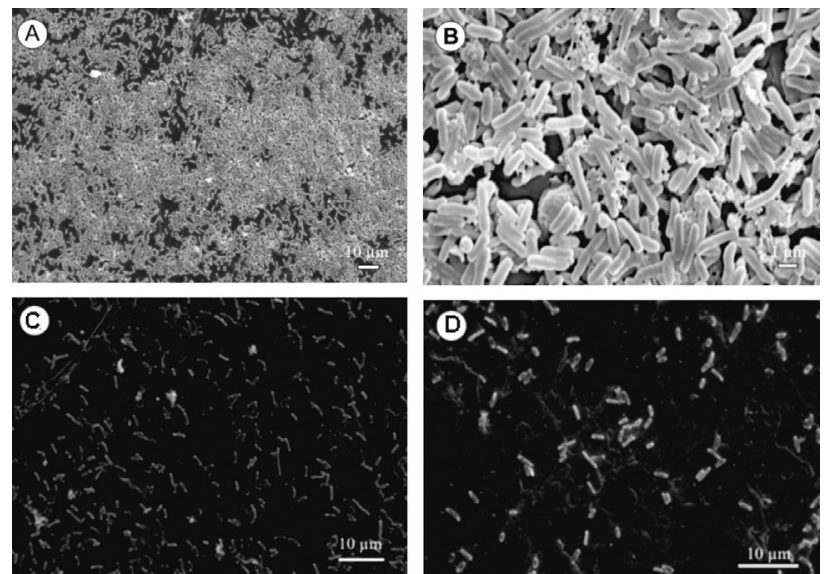

Figure 3 - Scanning Electron Micrographs: (A e B) Biofilm of Aeromonas hydrophila on stainless steel coupons after a period of 10 days and EPS formation (observe the circles); (C) Treatment of the biofilm using the thyme detergent-sanitizer solution and (D) Treatment of the biofilm using the lemongrass detergent-sanitizer solution.
Table 3 - Percentage of CFU $\mathrm{cm}^{-2}$ of Aeromonas hydrophila, observed after treatment of stainless steel coupons containing biofilm, with sanitizerdetergent and detergent solutions.

\begin{tabular}{lcc}
\hline Detergent* and Sanitizer-detergents & \multicolumn{2}{c}{$\mathrm{CFU} \mathrm{cm}^{-2}$ recovered (\%) } \\
\hline $\mathrm{NaOH}(1 \%)^{*}$ & 56.05 & $\mathrm{~A}$ \\
$\mathrm{NaOH}(1 \%)$ and thyme & 42.33 & $\mathrm{~B}$ \\
$\mathrm{NaOH}(1 \%)$ and lemongrass & 34.67 & $\mathrm{~B}$ \\
\hline
\end{tabular}

Averages followed by the same letter do not differ among themselves, by the Scott-Knott test, at 5\% significance.

1984). These results are similar to those reported by Oliveira et al. (2010), for C. citratus essential oil, the major constituents found were: geranial $(42.91 \%)$ and neral $(30.90 \%)$. The 1,8 cineol, a monoterpenoid compound, largely present in the thyme oil used in this work, also possesses antibacterial activity (Gilles et al., 2010), and has already been related as a possible main constituent of the thyme essential oil, depending on the stage of the plant development (Jordán et al., 2006). Differences in the composition of essential oils from plants of the same species are related to several factors that may be primarily genetic and environmental, climate, altitude, soil type, rainfall and others (Gobbo-Neto and Lopes, 2007).

The fact that C. citratus essential oil presented a high concentration of terpenoids suggests that such substances contributed to the high biocide performance of that essential oil at a lower concentration than that of the $T$ vulgaris essential oil. The antibacterial activities on Staphylococcus aureus and Escherichia coli were shown by Pereira et al. (2008). Works with T. vulgaris showed antibacterial activity on food spoiling and pathogenic bacteria, Gram negatives, such as Salmonella Typhimurium, there was formation of inhibition zones of $30 \mathrm{~mm}$, there was high sensitivity to essential oil (Rota et al., 2008). In our study with the Gram negative $A$. hydrophila, the results obtained are consistent with those found in literature.

The antibacterial action of the terpenes (main components of the lemongrass and thyme) is not completely understood. It is known, however, that it involves the rupture of the bacterial cytoplasmic membrane due to the lipophilic nature of such substances. The aforementioned interaction causes a fluidity and permeability increase of the cell membrane, the destruction of the membrane's proteins, inhibition of cell respiration and ion transport alterations (Cowan, 1999; Burt and Reinders, 2004; Woodling and Moraru, 2005).

Although the antimicrobial activity of the essential oils of various plants has been related, these works used planktonic cells, and few studies can be found in which the capacity of such oils to reduce biofilm on stainless steel surfaces were evaluated. Another importance factor of this study was the combined use of alkaline detergents and essential oil solutions, seeing as similar works cannot be found on literature. 
Aeromonas hydrophila is microorganism common in raw milk in cooling tanks at $4{ }^{\circ} \mathrm{C}$, with an increase in numbers after $24 \mathrm{~h}$ of storage of the milk (Lai et al., 2007). Once present, it can readily adhere to the stainless steel of the tank, producing biofilm (Lynch and Roberteson, 2002). In fact, the speed with which the cells adhere to the surface, forming biofilm which occupies the stainless steel's surface in a homogeneous way as was shown. Although the temperature used for the biofilm formation has been the optimum growth temperature for $A$. hydrophila that behavior still occurs even under inadequate conditions for its multiplication. Boari et al. (2009) showed that A. hydrophila formed biofilm when cultivated in UHT skimmed milk under 4,7 and $18^{\circ} \mathrm{C}$, and that at 7 and $18^{\circ} \mathrm{C}$ the biofilm had already been formed on the second day of cultivation, with counting of 5,14 log cfu cm $\mathrm{cm}^{-2}$ and 6,67 $\log \mathrm{cfu} \mathrm{cm} \mathrm{cm}^{-2}$, respectively. Steinberger and Holden (2005) showed that, the richer the environment where the Pseudomonas aeruginosa develops, the faster the biofilm forms. As the milk used was skimmed in that work, one may infer that its nutritional characteristics influenced in the rapid formation of the biofilm.

The milk, during the experiment, was replaced every $48 \mathrm{~h}$, providing fresh substratum, in order to avoid inhibition of the microorganism metabolic activity due to limitation of growth factors. The depletion of those factors occurs; therefore the consumption of the substratum or final electron acceptors occurs at a rate superior to that of biofilm replacement (Burt and Reinders, 2004). That happens because of the lower compound diffusion in the exopolysaccharides matrix, making them less available to the bacteria.

In spite of the sessile cells presenting differentiated microbial agent resistance characteristics (Werner et al., 2004), the antimicrobial potential of those substances on the cells is determined using planktonic cells, being one of the recommended techniques to determine the minimum inhibitory concentration in diffusion in agar. Thus, that methodology was employed with the biocide agents proposed in this work obtaining the inhibition zones and the oil concentrations that were used in the elaboration of the detergent-sanitizing solutions for evaluation of their activity on the A. hydrophila biofilm.

The detergent solution (alkaline solution) removed part of the A. hydrophila biofilm. However, its effectiveness was significantly lower compared to the treatments conducted with the sanitizing detergent solutions. In the Figures 3C and 3D can be seen that the essential oils breakage caused in the structure of EPS and dispersion of bacterial cells. Chorianopoulos et al. (2008) tested the activity of acid and base chemical disinfectants and also that of the essential oil of Satureja thymbra on biofilms formed by bacterial species on stainless steel coupons. The results showed that the $S$. thymbra essential oil presented satisfactory antimicrobial action on the biofilm formed by Salmonella enterica, with reduction of $4 \log$ cycles $\mathrm{cfu}^{\mathrm{cm}^{-2}}$. In the present research, similar results were observed. The treatment with the thyme and lemongrass detergent-sanitizing solutions reduced $A$. hydrophila by $4 \log \mathrm{cfu} \mathrm{cm}^{-2}$. In spite of not having used the combination of the essential oils, Oliveira et al. (2010) showed that a solution containing essential oils of $C$. citratus and $C$. nardus can reduce Listeria monocytogenes adhered cells on stainless steel by $100 \%$.

The sanitizers used in industry and in laboratory tests under conditions indicated by manufacturer, are approved in tests as suspension and use dilution, when they promote 5 decimal reductions (DR) after 30 seconds of contact at $20{ }^{\circ} \mathrm{C}$. But, in culture media, solid or liquid, there is no glycocalyx formation, fundamental to the adhesion process and protection of the cells on biofilm (Andrade and Macêdo, 1996). However, there is no established DR standard to consider a sanitizer as effective when the tested cells are sessile. Thus, the study chose to use time of 15 min of contact with the biofilm base sanitizing solutions of essential oils.

Some works such as the one of Lebert et al. (2007) investigated the efficiency of thymol and eugenol solutions and quaternary ammonium salt based sanitizer, and $S$. thymbra essential oil on multispecies biofilm formed by Pseudomonas fragi and Escherichia coli and pathogenic biofilm formed by $S$. aureus and L. monocytogenes. The quaternary ammonium salt is a traditional bactericide used in food industry. When the essential oil of $S$. thymbra was used at $1 \%$ and $2 \%$, there was reduction of the spoilage bacteria of $5.1 \log$ for E. coli and 5.2 for L. monocytogenes, but the pathogenic bacteria were not reduced sufficiently: 1.3 $\log$ for S. aureus and $2.5 \log$ for L. monocytogenes. With the combination of the quaternary ammonium compound with thymol and/or eugenol, a reduction in the inhibition of the biofilm was observed. According to the authors, the thymol did not present solubility in the compound based on the quaternary ammonium salt forming an emulsion to promote the mixture of the compounds.

According to the results demonstrated in this research, in spite of there not being significant statistical difference between the thyme and lemongrass sanitizerdetergents, the lemongrass sanitizer-detergent promoted a reduction of $1 \mathrm{log}$ above that obtained with the thyme, which was considered relevant. Keeping in mind the conditions of the medium, the microorganism in question and its generation time, this difference is important, because it can result in more efficient mitigation of the contamination of products and of the transmission of diseases. Thus, we suggest further research on search strategies using natural antimicrobials against bacterial biofilms, there are few studies on this perspective, but the studies already conducted have shown promising results.

\section{Acknowledgments}

To Coordenação de Aperfeiçoamento de Pessoal de Nível Superior (CAPES) and Fundação de Amparo a Pes- 
quisa do Estado de Minas Gerais (FAPEMIG) for the financial support.

\section{References}

Adams RP (2007) Identification of Essential Oils Components by Gas Chromatography/Quadrupole Mass Spectroscopy. Allured Publishing, Carol Stream, 455 pp.

Alves E (2004) Introdução a Microscopia Eletrônica de Varredura. Editora UFLA, Lavras, 43 pp.

Andrade NJ, Macêdo JAB (1996) Higienização na Indústria de Alimentos. Varela, São Paulo, 182 pp.

Barbosa LN, Rall VLM, Fernandes AAH, Ushimaru PI, Probst S, Fernandes Júnior A (2009) Essential oils against foodborne pathogens and spoilage bacteria in minced meat. F Pat Dis 6:725-728.

Boari CA, Alves MP, Reis VM, Savian TV, Piccoli RH (2009) Formação de biofilme em aço inoxidável por Aeromonas hydrophila e Staphylococcus aureus usando leite e diferentes condições de cultivo. Ciênc Tecnol Aliment 29:886895.

Burt SA, Reinders RD (2004) Antibacterial activity of selected plant essential oils against Escherichia coli O157:H7. Lett Appl Microb 36:162-167.

Cardoso MJ, Carvalho Leal HW, Santos MX (2000) Estabilidade de cultivares de milho no Estado do Piauí. Rev Cient Rural 5:62-67.

Castro DP, Cardoso MG, Moraes JC, Santos NM, Baliza DP (2006) Não preferência de Spodoptera frugiperda (Lepdóptera, Noctuidae) por óleos essenciais de Achillea millefolium L. e Thymus vulgaris. Rev Bras Plan Med 8:2732.

Chavant P, Gaillard-Mertinie B, Talon R, Hébraud M, Bernardi T (2007) A new device for rapid evaluation of biofilm formation potential by bacteria. J Microbiol Method 68:605-612.

Chorianopoulos NG, Giaouris ED, Skandamis PN, Haroutounaian SA, Nychas GJE (2008) Disinfectant test against monoculture and mixed-culture biofilms composed of technological, spoilage and pathogenic bacteria: bactericidal effect of essential oil and hydrosol of Satureja thymbra and comparison with standard acid-base sanitizers. J Appl Microbiol 104:1364-5072.

Costerton JW (2005) Biofilm theory can guide the treatment of device-related orthopaedic infections. Clin Orthop Rel Res 437:7-11.

Cowan MM (1999) Plant products as antimicrobial agents. Clin Microbiol Rev 12:564-582.

Danielsen M, Mayrhofer S, Domig CJ, Amtmann E, Mayer HK, Flórez AB, Mayo B, Korhonen J, Tosi L (2008) Assessment of the antimicrobial wild-type minimum inhibitory concentration distributions of species of the Lactobacillus delbrueckii group. Dairy Sci Technol 88:183-191.

Deans SG, Ritchie G (1987) Antibacterial properties of plant essential oils. Int J Food Microbiol 5:165-180.

Essawi T, Srour M (2000) Screening of some Palestinian medicinal plants for antibacterial activity. J Ethnophacol 70:343349.

Gandhi M, Chikindas ML (2007) Listeria: a foodborne pathogen that knows how to survive. Int J Food Microbiol 113:1-15.

Gavín R, Rabaan AA, Merino S, Tomás JM, Gryllos I, Shaw JG (2002) Lateral flagella of Aeromonas species are essential for epithelial cell adherence and biofilm formation. Molec Microbiol 43:383-397.

Gilles M, Zhao J, An M, Agboola S (2010) Chemical composition and antimicrobial properties of essential oils of three Australian Eucalyptus species. Food Chemis 119:731-737.

Gobbo-Neto L, Lopes NP (2007) Plantas medicinais: fatores de influência no conteúdo de metabolitos secundários. Quím Nov 30:374-381.

Jordán MJ, Martínez RM, Goodner KL, Baldwin EA, Sotomayor JA (2006) Seasonal variation of Thymus hyemalis Lange and Spanish Thymus vulgaris L. essential oils composition. Ind Crops Produc 24:253-263.

Joseph SW, Carnahan AM (2003) Update of the genus Aeromonas. ASM News 41:218-223.

Lafarge V, Ogier JC, Girard V, Maladen V, Leveau JY, Gruss A (2004) Raw cow milk bacterial population shifts attributable to refrigeration. Appl Environ Microbiol 70:5644-5650.

Lai CC, Shiao CC, Lu GD, Ding LW (2007) Aeromonas hydrophila and Aeromonas sobria bacteremia: rare pathogens of infection in a burn patient. Burns 33:255-257.

Lebert TI, Leroy S, Talon R (2007) Effect of industrial and natural biocides on spoilage, pathogenic and technological strains grown in biofilm. Food Microbiol 24:281-287.

Lynch AS, Roberteson GT (2002) Bacterial and fungal biofilm infections. Annual Review Med 59:415-428.

Marques SC, Resende JGOS, Alves LAF, Silva BC, Abreu LR, Alves E, Piccoli RH (2007) Formation of biofilms by Staphylococcus aureus on surfaces of stainless steel and glass and its resistance to some selected chemical sanitizers. Braz J Microbiol 38:538-554.

Marrins ER, Castro DM, Castellani DC, Dias JE (1994) Plantas Medicinais. UFV, Viçosa, $220 \mathrm{pp}$.

Millezi FM, Pereira MO, Batista NN, Camargos N, Auad I, Cardoso MDG, Piccoli RH (2012a) Susceptibility of monospecies and dual-species biofilms of Staphylococcus aureus and Escherichia coli to essential oils. J Food Saf 32:351359.

Millezi AF, Caixeta DS, Rossoni DF, Cardoso MG, Piccoli RH (2012b) In vitro antimicrobial properties of plant essential oils thymus vulgaris, cymbopogon citratus and laurus nobilis against five important foodborne pathogens. Ciênc Tecnol Aliment 32, Epub.

Ogunwande IA, Olawore NO, Ekundayo O, Walter TM, Schimidt JM, Setzer WN (2005) Studies on the essential oils composition, antibacterial and cytotoxicity of Eugenia uniflora L. Int J Aromath 2:147-152.

Oliveira MMM, Brugnera DF, Cardoso MG, Alves E, Piccoli RH (2010) Disinfectant action of Cymbopogon sp. essential oils in different phases of biofilm formation by Listeria monocytogenes on stainless steel surface. Food Control 21:549-553.

Onawunmi GO, Yisak W, Ogunlana EO (1984) Antibacterial constituents in the essential oil of Cymbopogon citratus (DC) Stapf. J Etnopharmac 12:279-286.

Pereira AA, Cardoso MG, Ronaldo LR, Morais AR, Guimarães LG, Salgado APP (2008) Caracterização química e efeito inibitório de óleos essenciais sobre o crescimento de Staphylococcus aureus e Escherichia coli. Rev Cien Agrotec 32:887-893.

Prigent-Combaret C, Lejeune P (1999) Monitoring gene expression in biofilms. Meth Enzymol 310:56-79. 
R Development Core Team (2008) R: A language and environment for statistical computing, reference index ver. 2.8.0. R Foundation for Statistical Computing Vienna, available at: http://www.R-project.org. Accessed: Dec 12, 2008.

Rota CM, Herrera A, Martínez RM, Sotomayor JA, Jordán MJ (2008) Antimicrobial activity and chemical composition of Thymus vulgaris, Thymus zygis and Thymus hyemalis essential oils. Food Control 19:681-687.

Silva N, Junqueira VCA, Silveira NFA, Taniwaki MH, Santos RFS, Gomes RAR (2010) Manual de Métodos de Análise Microbiológica de Alimentos e Água. 4 ed. Varela, São Paulo, 624 pp.

Sotomayor JA, Martínez RM, García AJ, Jordán MJ (2004) Thymus zygis subsp. Gracilis: watering level effect on phytomass production and essential oil quality. J Agric Food Chem 52:5418-5424.

Steinberger RE, Holden PA (2005) Extracellular DNA in Singleand Multiple-Species Unsaturated Biofilms. Appl Environ Microbiol 71:5404-5410.
Suñen E, Aristimuño C, Fernandez-Galian B (2003) Activity of smoke wood condensates against Aeromonas hydrophila and Listeria monocytogenes in vacuum-packaged, coldsmoked rainbow trout stored at $4{ }^{\circ} \mathrm{C}$. Food Research Int 36:111-116.

Trombetta D, Castelli F, Sarpietro MG, Venuti V, Cristani M, Daniele C, Saija A, Mozzanti G, Bisignsno G (2005) Mechanisms of antibacterial action of three monoterpenes. Antimicrob. Agents Chemoth 49:2474-2478.

Werner E, Roe F, Bugnicourt A, Franklin MJ, Heydorn A, Molin S, Pitts BS (2004) Growth in Pseudomonas aeruginosa Biofilms. Appl Environm Microbiol 70:6188-6196.

Woodling SE, Moraru CI (2005) Influence of surface topography on the effectiveness of pulsed light treatment for the inactivation of Listeria innocua on stainless-steel surfaces. J Food Sci 70:345-351.

All the content of the journal, except where otherwise noted, is licensed under a Creative Commons License CC BY-NC. 